\title{
ANALISIS KOMPONEN ASAM AMINO IKAN LAYANG DELES (Decapterus Makrosoma) HASIL OLAHAN TRADISIONAL BERDASARKAN LAMA PENYIMPANAN
}

\author{
Vhindra Engson Lumamuly ${ }^{1}$, Nikmans Hattu ${ }^{2}$, dan Samuel Unwakoly ${ }^{1}$ \\ ${ }^{1}$ Departement of Chemistry-FKIP, Pattimura University Ambon \\ ${ }^{2}$ Departement of Chemistry-MIPA, Pattimura University Ambon
}

Diterima 15 Mei 2019/Disetujui 25 Juni 2019

\begin{abstract}
The aim of this study was to determine the amino acid composition of traditional processed Layang Deles fish (Decapterus macrosoma) which was stored for 2 months. Analysis of amino acid content using by Ultra Performance Liquid Chromatography (UPLC) instrument after content of water and lipid in sample was removed. The results of the analysis showed that there was a change in the concentration of 15 amino acids measured ranging from $85.17 \%$ to $2,873.42 \%$ in acid hydrolysis and $88.18 \%$ to $28.73 \%$ in alkaline hydrolysis. The biggest changes occurred in histidine, arginine and serine amino acid concentrations of 2,873.42\%, 2,606.74\% and $900.00 \%$ in acid hydrolysis and in amino acids serine, aspartic acid and histidine which were $88.17 \%, 62,99 \%$ and $40.02 \%$ in alkaline hydrolysis. Based on the results of the research, it can be concluded that the processing of inmana fish with a storage period of 2 months affects the amino acid components of Layang Deles fish (Decapterus macrosoma).
\end{abstract}

Keywords: Amino acids, hydrolysis, Layang Deles fish, Ultra Performance Liquid Chromatography (UPLC)

\begin{abstract}
ABSTRAK
Penelitian ini bertujuan untuk mengetahui komposisi asam amino dalam ikan Layang Deles (Decapterus makrosoma) hasil olahan tradisional (ikan inmana) yang disimpan selama 2 bulan. Analisis kadar asam amino dilakukan menggunakan instrumen Ultra Performance Liquid Chromatography (UPLC) setelah kandungan air dan lemak dihilangkan. Hasil analisis menunjukan bahwa terjadi perubahan konsentrasi 15 jenis asam amino yang diukur berkisar antara $85,17 \%$ sampai dengan $2.873,42 \%$ pada hidrolisis asam dan antara $88,18 \%$ sampai dengan $28,73 \%$ pada hidrolisis basa. Perubahan terbesar terjadi pada konsentrasi asam amino histidin, arginin dan serin yakni sebesar $2.873,42 \%, 2.606,74 \%$ dan $900,00 \%$ pada hidrolisis asam dan pada asam amino serin, asam aspartat dan histidin yakni sebesar $88,17 \%, 62,99 \%, 40,02 \%$ pada hidrolisis basa. Berdasarkan hasil penelitian yang telah dilakukan dapat disimpulkan bahwa pengolahan ikan inmana dengan lama penyimpanan 2 bulan mempengaruhi komponen asam amino ikan Layang Deles (Decapterus makrosoma).
\end{abstract}

Kata Kunci: Asam amino, Hidrolisis, Ikan Layang Deles, Ultra Performance Liquid Chromatography (UPLC)

\section{PENDAHULUAN}

Indonesia memiliki sumber daya hayati yang sangat melimpah. Kekayaan hayati tersebut di antaranya adalah ikan, yang memiliki manfaat kesehatan dan ekonomi. Hal ini karena ikan memiliki kandungan gizi yang baik serta dapat memberi keuntungan dari segi ekonomi dengan nilai jual yang tinggi. Kandungan gizi yang utama pada ikan adalah protein dan asam-asam lemak esensial yang sangat berguna bagi kesehatan manusia (Hafiludin, 2011).

Ikan memegang peranan penting dalam pemenuhan gizi manusia karena kandungan utama ikan adalah protein (Mazrouh, 2015). Ikan juga berfungsi sebagai sumber dari asam lemak tidak jenuh 
jamak (PUFA), protein, mineral dan vitamin. Dibandingkan sumber lainnya, keunggulan utama protein ikan terletak pada kelengkapan komposisi asam aminonya dan kemudahan untuk dicerna (Winarno, 2004).

Ikan merupakan salah satu sumber protein hewani yang banyak dikonsumsi masyarakat, mudah didapat, dan harganya murah. Namun ikan cepat mengalami proses pembusukan dan penurunan mutu dikarenakan daging ikan mempunyai kadar air yang tinggi, $\mathrm{pH}$ netral, teksturnya lunak, dan kandungan gizinya tinggi sehingga menjadi medium yang sangat baik untuk pertumbuhan bakteri sehingga mengakibatkan ikan tidak dapat disimpan dalam waktu yang lama untuk dikonsumsi (Riansyah dkk., 2013). Oleh karena itu, untuk memperpanjang masa simpan, masyarakat biasanya melakukan teknik pengolahan dan pengawetan ikan hasil tangkapan. Salah satu pengolahan yang masih sering dipakai adalah teknik secara tradisional seperti pengasapan, pengeringan, penggaraman, dan fermentasi (Paparang, 2013).

Diantara berbagai teknik pengolahan tersebut, hampir 50\% ikan hasil tangkapan diolah secara tradisional menjadi ikan asin dengan cara pengasinan atau penggaraman. Penggaraman adalah salah satu cara pengawetan ikan segar agar tidak mengalami pembusukan yang diakibatkan oleh bakteri pembusuk dengan menambahkan garam 15-20\% dari bobot ikan segar atau ikan setengah basah (Salosa, 2013).

Penggaraman merupakan cara pengawetan ikan dengan menggunakan garam sebagai media pengawet. Ikan yang diawetkan dengan garam kita sebut ikan asin. Garam dapat mengawetkan ikan melalui proses menunda atau menghilangkan autolisis dan membunuh bakteri secara langsung. Mekanisme pengawetannya adalah garam menyerap cairan dari tubuh ikan melalui proses osmosis, sehingga air yang tersedia bagi bakteri untuk berkembang biak menjadi berkurang. Kekurangan air menyebabkan metabolisme bakteri terganggu. Selain itu, garam akan menyerap air dari tubuh bakteri sehingga bakteri akan mengalami kekeringan dan mati (Murniyanti \& Sunarman, 2000). Sebagai pengawet, garam bertindak sebagai humektan karena sifatnya yang mudah larut dalam air dan menyerap air bahan (higroskopis), sehingga dapat menurunkan kadar air (Buckle dkk., 1985).

Teknik pengolahan ikan secara tradisional ini juga digunakan oleh masyarakat pada daerahdaerah di Provinsi Maluku. Salah satunya di Desa Waipia, Kecamatan TNS Kabupaten Maluku Tengah. Masyarakat di daerah ini mengolah ikan hasil tangkapan dengan menambahkan garam pada daging ikan yang sebelumnya telah dibersihkan, kemudian disimpan selama satu malam. Setelah itu, ikan akan dimasukkan dalam wadah, ditambahkan nira kelapa, dan disimpan untuk nantinya dikonsumsi. Ikan olahan ini biasanya dikonsumsi setelah waktu penyimpanan beberapa bulan dan dikonsumsi oleh sebagian besar masyarakat di sana. Ikan olahan tradisional ini dikenal dengan nama inmana.

Beberapa penelitian telah dilakukan untuk mempelajari pengaruh proses pengawetan terhadap mutu ikan. Paparang (2013) telah melakukan eksperimen tentang pengaruh variasi konsentrasi garam terhadap cita rasa ikan peda dengan menggunakan kadar lemak sebagai salah satu parameter. Hasil penelitiannya menunjukkan bahwa kadar lemak mengalami penurunan dengan meningkatnya konsentrasi garam yang diberikan yaitu 4,76\%, 4,57\%, dan 4,51\% berturut-turut pada konsentrasi garam 10, 15 dan $20 \%$.

Haris (2013) juga telah menganalisis pengaruh penggaraman terhadap protein ikan layang dengan menggunakan metode Kjeldahl untuk menentukan $\mathrm{N}$ total pada setiap sampel dan metode Elektroforesis Gel (SDS-PAGE) untuk menentukan berat molekul (BM), mendeteksi kemurnian dan kerusakan protein. Hasil penelitian menggunakan metode Kjeldahl diperoleh $\mathrm{N}$ total pada sampel ikan segar adalah sebesar 3,09\%. Sementara itu, pada sampel ikan yang diberi perlakuan garam $0 \%, 10 \%, 20 \%, 30 \%$, dan $40 \%$ berturut-turut adalah 0,32\%, 2,59\%, 3,16\%, 2,70\%, dan 3,19\%. Berat molekul protein ikan layang yang ditentukan dengan metode SDS-PAGE pada sampel ikan yang diberi perlakuan penggaraman $0 \%, 10 \%, 20 \%, 30 \%$, dan $40 \%$ berturut-turut adalah $31,58-49,2 \mathrm{kDa}$, $32,36-51,44 \mathrm{kDa}, 31,46-50,76 \mathrm{kDa}, 30,79-52,1 \mathrm{kDa}$, dan $34,17-55,03 \mathrm{kDa}$. Hasil penelitiannya menyimpulkan bahwa penggaraman pada ikan berpengaruh terhadap protein ikan terutama pada 
proses denaturasi protein. Walaupun demikian, kandungan $\mathrm{N}$ total pada setiap sampel tidak berbeda signifikan kecuali pada sampel ikan yang tidak diberi $\mathrm{NaCl}(0 \%)$.

Rumahlaiselan (2016) telah menganalisis komponen asam lemak pada ikan olahan tradisional (ina sua) pada ikan kakap merah (Lutjanus sp). Ikan ina sua adalah nama lain dari ikan inmana. Isolasi lemak atau minyak ikan dilakukan dengan metode ekstraksi sohxlet menggunakan pelarut klorofom dan metanol. Hasil penelitian menunjukkan bahwa kandungan asam lemak dalam ikan kakap segar, ikan kakap olahan ina sua basah dan kering berturut-turut adalah sebesar $17,79 \%, 16,53 \%$, dan $18,22 \%$. Hal ini dapat menjelaskan adanya pengaruh penggaraman terhadap komposisi ikan.

Tidak hanya protein, gizi lainnya seperti asam amino kemungkinan mengalami penurunan. Oleh karena itu, perlu dilakukan penelitian untuk menganalisis kandungan asam amino pada ikan hasil olahan tradisional dari masyarakat Desa Waipia, Kecamatan TNS, Kabupaten Maluku Tengah. Lamanya waktu penyimpanan ikan olahan tradisional kemungkinan juga mempengaruhi mutu ikan. Ikan yang umumnya dijadikan produk olahan inmana salah satunya adalah ikan Layang Deles (Decapterus makrosoma). Ikan ini banyak dijual di pasar komersial dan juga ditangkap oleh nelayan lokal.

Berdasarkan latar belakang yang telah dijelaskan, maka yang menjadi permasalahan dalam penelitian ini adalah bagaimana perubahan komposisi asam amino pada ikan Layang Deles (Decapterus makrosoma) hasil olahan tradisional (ikan inmana) setelah disimpan selama 2 bulan?

\section{METODE PENELITIAN}

\section{A. Waktu dan Tempat Penelitian}

Preparasi sampel dilakukan di Laboratorium Kimia FKIP Universitas Pattimura pada bulan Oktober-Desember 2017, hidrolisis asam dan basa dilakukan di Laboratorium Kimia Dasar FMIPA Universitas Pattimura pada bulan Januari 2018 dan analisis komponen asam amino dengan UPLC dilakukan pada PT. Saraswanti Indo Genetech Bogor, pada bulan April 2018.

\section{B. Alat dan Bahan}

1. Alat

Peralatan yang digunakan dalam penelitian ini adalah:

a. Seperangkat alat ekstraksi Soxhlet

b. Seperangkat alat refluks

c. Peralatan gelas (Pyrex)

d. Neraca analitik ohaus

e. Blender makanan (Miyako)

f. Oven

g. Stopwatch

h. UPLC AccQ. Tag Ultra C18 1,7 $\mu \mathrm{m}(2,1 \times 100 \mathrm{~mm})$

\section{Bahan}

Bahan-bahan yang digunakan dalam penelitian ini adalah:

a. Ikan Layang Deles (Decapterus makrosoma)

b. Petroleum benzena p.a (E.merck)

c. Dietil eter p.a (E.merck)

d. Asam Sulfat $\left(\mathrm{H}_{2} \mathrm{SO}_{4}\right)$ p.a (E.merck)

e. Barium Hidroksida $\mathrm{Ba}(\mathrm{OH})_{2}$ p.a (E.merck)

f. Kertas saring (Whatman 42)

g. Garam dapur 
h. Aquades

i. Indikator Universal

\section{Prosedur Kerja}

\section{Pembuatan Ikan Inmana}

Ikan Layang Deles (Decapterus makrosoma) segar sebanyak 2 ekor dibersihkan dengan cara melepaskan bagian tulang, sirip dan kemudian masing-masing difilet menjadi dua bagian. Setelah dibersihkan, 1 ekor ikan kemudian dilakukan proses preparasi dan 1 ekor lainnya dilakukan penggaraman dengan cara menaburi garam sebanyak $100 \mathrm{~g}$, kemudian disimpan selama satu malam. Ikan dimasukkan dalam wadah, ditambahkan $200 \mathrm{~mL}$ nira kelapa dan disimpan selama 2 bulan.

\section{Preparasi Sampel}

Daging ikan inmana dipotong menjadi beberapa bagian kemudian dikeringkan menggunakan oven pada suhu $60^{\circ} \mathrm{C}$ sampai berat konstan. Daging ikan kemudian dihaluskan menggunakan blender hingga menjadi serbuk yang selanjutnya digunakan dalam proses ekstraksi. Tahapan yang sama juga dilakukan pada ikan Layang Deles segar.

\section{Ekstraksi Soxhlet}

Serbuk sampel yang telah ditimbang $( \pm 50 \mathrm{~g})$ dibungkus menggunakan kertas saring dan dimasukkan dalam ekstraktor, kemudian diekstraksi dengan menggunakan pelarut dietil eter dan petroleum benzene (2:1). Ekstraksi dilakukan sampai pelarut dalam ekstraktor menjadi tak berwarna. Ekstrak yang diperoleh kemudian dikeringkan dalam oven pada suhu $70^{\circ} \mathrm{C}$, diuapkan dalam desikator dan ditimbang. Proses ini diulangi sampai diperoleh berat konstan.

\section{Hidrolisis Protein}

Serbuk sampel yang bebas air dan lemak, kemudian dihidrolisis secara asam dan basa untuk memperoleh komponen-komponen asam amino bebas. Dalam penelitian ini, digunakan $\mathrm{H}_{2} \mathrm{SO}_{4} 6 \mathrm{M}$ untuk hidrolisis asam dan $\mathrm{Ba}(\mathrm{OH})_{2} 6 \mathrm{M}$ untuk hidrolisis basa.

\section{a. Analisis Komponen Asam Amino secara hidrolisis asam}

Sebanyak 1,0004 g serbuk sampel ikan inmana yang bebas lemak, direfluks menggunakan 6 $\mathrm{mL} \mathrm{H}_{2} \mathrm{SO}_{4} 6 \mathrm{M}$ pada suhu $110^{\circ} \mathrm{C}$ selama $12 \mathrm{jam}$, setelah itu larutan dinetralkan dengan cara menambahkan $\mathrm{Ba}(\mathrm{OH})_{2} 6 \mathrm{M}$ secara perlahan-lahan sampai $\mathrm{pH}$ netral. Larutan disaring dan filtratnya diencerkan dalam labu takar $50 \mathrm{~mL}$ sampai tanda batas, kemudian dimasukan ke dalam botol sampel dan dianalisis menggunakan UPLC.

b. Analisis Komponen Asam Amino secara hidrolisis Basa

Sebanyak $1,0004 \mathrm{~g}$ serbuk sampel ikan inmana yang bebas lemak, direfluks menggunakan 6 $\mathrm{mL} \mathrm{Ba}(\mathrm{OH})_{2} 6 \mathrm{M}$ pada suhu $110^{\circ} \mathrm{C}$ selama 12 jam, setelah itu larutan dinetralkan dengan cara menambahkan $\mathrm{H}_{2} \mathrm{SO}_{4} 6 \mathrm{M}$ secara perlahan-lahan sampai $\mathrm{pH}$ netral. Larutan disaring dan filtratnya diencerkan dalam labu takar $50 \mathrm{~mL}$ sampai tanda batas, kemudian dimasukan ke dalam botol sampel dan dianalisis menggunakan UPLC.

\section{HASIL PENELITIAN}

\section{A. Analisis Kadar Air dan Kadar Lemak}

Sebelum dilakukan analisis komponen asam amino, dilakukan analisis kadar air dengan cara dikeringkan menggunakan oven pada suhu $50-60^{\circ} \mathrm{C}$ selama 7 hari. Menurut Yuarni dkk., (2015), kadar air semakin menurun dengan semakin lama dilakukan pengeringan. Hal ini disebabkan karena suhu tinggi dapat menguapkan kandungan air yang ada di dalam tubuh ikan. Sementara itu, analisis kadar lemak dilakukan menggunakan metode soxhletasi. Data analisis kadar air dan lemak diperlihatkan pada Tabel 1. 
Tabel 1. Hasil Analisis Kadar Air dan Kadar Lemak

\begin{tabular}{lll}
\hline Parameter & $\begin{array}{l}\text { Ikan Layang } \\
\text { Segar (\%) }\end{array}$ & $\begin{array}{l}\text { Ikan } \\
\text { Inmana (\%) }\end{array}$ \\
\hline Kadar Air & 81,06 & 63,02 \\
Kadar Lemak & 10,15 & 11,89 \\
\hline
\end{tabular}

Berdasarkan hasil anälisis pada Tabel 1, ikan Layang Deles segar memiliki kadar air lebih tinggi dibandingkan dengan ikan inmana. Hal ini disebabkan karena penggunaan garam dalam proses pembuatan ikan inmana, menyebabkan penyerapan kandungan air sehingga kandungan air menurun. Kadar garam yang tinggi akan melakukan penyerapan yang besar pula terhadap kandungan air di dalam bahan makanan. Menurut Susilowati (2010), fermentasi dengan garam menghasilkan kandungan air yang cenderung mengalami penurunan selama proses fermentasi. Penurunan kandungan air ini disebabkan oleh adanya hidrasi ion-ion garam yang menarik ion molekul air suatu bahan pangan. Penurunan kadar air tersebut terjadi karena garam dalam proses penggaraman akan berpenetrasi ke dalam tubuh ikan. Garam yang masuk ke dalam tubuh ikan akan menggantikan air bebas yang ada pada tubuh ikan (bersifat higroskopis). Selain itu, kadar air yang tinggi dalam sampel, akan menyebabkan emulsi dan mengganggu proses penyerapan pelarut pada saat proses ekstraksi lemak.

Sampel yang bebas air kemudian diekstrasi dengan metode soxhletasi untuk mengisolasi kandungan minyak agar tidak mempengaruhi analisis komponen asam amino pada sampel. Ekstraksi dilakukan menggunakan pelarut dietil eter dan petroleum benzena dengan perbandingan 2:1. Penggunaan pelarut ini dikarenakan lebih selektif, volatil dan bersifat nonpolar, sesuai untuk mengisolasi senyawa yang bersifat nonpolar seperti minyak. Hasil analisis menunjukkan bahwa kandungan minyak pada sampel ikan Layang Deles segar sebesar 10,15\% atau lebih kecil dibandingkan dengan kandungan minyak ikan inmana yang telah direndam selama 2 bulan yakni $11,89 \%$. Hal ini disebabkan karena dengan adanya proses pengeringan dan penambahan garam dalam pengolahan ikan asin, menyebabkan berkurangnya kadar air, sedangkan kadar lemak ada dalam konsentrasi yang tinggi.

Reo (2013) menemukan bahwa nilai kadar lemak yang diperoleh pada setiap konsentrasi larutan garam dan lama pengeringan mengalami peningkatan. Persentase peningkatan kadar lemak tertinggi terjadi pada perlakuan dan konsentrasi larutan garam 15\% (kadar lemaknya 6,87\%) hingga $17 \%$ (kadar lemaknya 11,03) dengan lama pengeringan 10 jam. Sementara itu, persentase peningkatan kadar lemak terendah terjadi pada perlakuan dari konsentrasi larutan garam 13\% (kadar lemaknya 6,10\%) hingga 15\% (kadar lemaknya 6,87\%) dengan lama pengeringan 10 jam. Sejalan dengan itu, Hutuely dkk., (1991), dalam Riansyha dkk., (2013), menyatakan bahwa garam yang digunakan dalam proses pengasinan akan diserap ke dalam daging ikan dan mengurangi kadar air, sehingga bahan pangan akan mengandung senyawa-senyawa seperti protein, karbohidrat, lemak dan mineral dalam konsentrasi yang lebih tinggi, tetapi vitamin-vitamin dan zat warna pada umumnya akan berkurang.

\section{B. Analisis Komponen Asam Amino Ikan Layang Deles (Decapterus makrosoma) segar dan ikan Inmana yang dihidrolisis secara asam}

Analisis 15 komponen asam amino ikan Layang Deles (Decapterus makrosoma) segar dan hasil olahan inmana dilakukan dengan menggunakan instrumen Ultra Performance Liquid Chromatograpy (UPLC). Sebelum dianalisis, kedua sampel dihidrolisis secara (i) asam dan (ii) basa. Tujuan dilakukan hidrolisis adalah untuk memutuskan rangkaian ikatan peptide sehingga menghasilkan komponenkomponen asam amino bebas. 


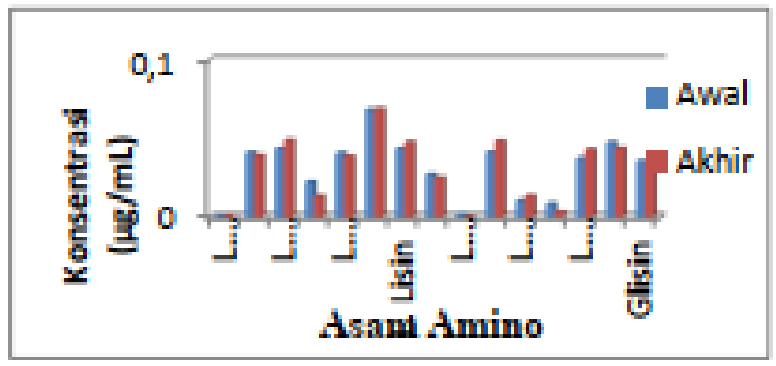

Gambar 1. Histogram Konsentrasi Asam Amino

Ikan Layang Deles yang dihidrolisis secara asam sebelum dan sesudah pengolahan terhadap 15 jenis asam amino, menunjukkan peningkatan konsentrasi terhadap 13 jenis asam amino dan penurunan konsentrasi pada 2 jenis asam amino. Meningkatnya konsentrasi asam amino ini disebabkan karena terjaganya suasana asam yang berasal dari hasil fermentasi nira kelapa serta penggunaan garam yang berfungsi menyerap air, sehingga bakteri pembusuk akan mati. Hal ini menyebabkan kondisi ikan tetap terjaga untuk masa penyimpanan selama 2 bulan. Selain itu, asam amino yang mengalami penurunan konsentrasi, dapat diakibatkan oleh adanya proses hidrolisis secara asam. Hidrolisis asam dapat mengakibatkan terbentuknya humin atau bahan-bahan lain serupa humin yang secara kompleks memisahkan asam amino dan hidrolisat (Johnson dan Peterson, (1974) dalam Purbasari, 2008). Secara spesifik, peningkatan dan penurunan konsentrasi asam amino sebelum dan sesudah pengolahan yang dhirolisis secara asam, terlihat pada Tabel 2.

Tabel 2. Hasil analisis konsentrasi asam amino ikan layang segar dan ikan inmana yang dihidrolisis secara asam

\begin{tabular}{|c|c|c|c|c|c|c|}
\hline \multirow[t]{2}{*}{$\mathbf{N}$} & \multirow{2}{*}{ Asam Amino } & \multicolumn{2}{|c|}{ Konsentrasi (mg/Kg) } & \multicolumn{2}{|c|}{ Perubahan konsentrasi } & \multirow[b]{2}{*}{ Ket } \\
\hline & & Awal & Akhir & $(\mathrm{mg} / \mathrm{kg})$ & $\%$ & \\
\hline I & Asam Amino Esensia & & & & & \\
\hline 1. & L. Threonin & 0,2379 & 0,2548 & 0,0169 & 7,10 & $\uparrow$ \\
\hline 2. & L. Valin & 0,3368 & 0,5617 & 0,2249 & 66,78 & $\uparrow$ \\
\hline 3. & L. Fenilalanin & 0,3198 & 0,4648 & 0,1450 & 45,34 & $\uparrow$ \\
\hline 4. & L. Histidin & 0,0079 & 0,2349 & 0,2270 & 2873,42 & $\uparrow$ \\
\hline 5. & L. Isoleusin & 0,0329 & 0,0533 & 0,0204 & 62,01 & $\uparrow$ \\
\hline 6. & L. Leusin & 0,5117 & 0,8346 & 0,3229 & 63,10 & $\uparrow$ \\
\hline 7. & L. Lisin & 0,6197 & 0,0919 & 0,5278 & 85,17 & $\downarrow$ \\
\hline II & Asam Amino non-Ese & ensial & & & & \\
\hline 1. & L. Prolin & 0,1979 & 0,2788 & 0,0809 & 40,87 & $\uparrow$ \\
\hline 2. & L. Serin & 0,0009 & 0,0099 & 0,0081 & 900,00 & $\uparrow$ \\
\hline 3. & L. Tirosin & 0,3018 & 0,4208 & 0,1190 & 39,43 & $\uparrow$ \\
\hline 4. & L. Arginin & 0,0089 & 0,2409 & 0,2320 & 2606,74 & $\uparrow$ \\
\hline 5. & L. Asam Aspartat & 0,0339 & 0,0219 & 0,0120 & 35,40 & \\
\hline 6. & L. Asam Glutamat & 0,6157 & 0,7906 & 0,1749 & 28,40 & $\uparrow$ \\
\hline 7. & L. Alanin & 0,4098 & 0,4288 & 0,0190 & 4,64 & 个 \\
\hline 8. & Glisin & 0,2239 & 0,3338 & 0,1099 & 49,08 & $\uparrow$ \\
\hline
\end{tabular}

Keterangan : $\uparrow=$ kenaikan ; $\downarrow=$ mengalami penurunan 
Berdasarkan Tabel 2 terlihat bahwa konsentrasi asam amino ensensial tertinggi ikan Layang Deles segar adalah lisin yaitu sebesar $0,6197 \mathrm{mg} / \mathrm{kg}$, sedangkan yang terendah adalah histidin yaitu sebesar $0,0079 \mathrm{mg} / \mathrm{kg}$. Sementara itu, konsentrasi asam amino non-esensial yang tertinggi adalah asam glutamat yaitu sebesar $0,6157 \mathrm{mg} / \mathrm{kg}$, sedangkan yang terendah adalah serin yaitu sebesar $0,0009 \mathrm{mg} / \mathrm{kg}$. Setelah diolah menjadi ikan inmana dan disimpan selama 2 bulan, konsentrasi asam amino esensial yang mengalami peningkatan tertinggi adalah histidin yaitu sebesar $0,2270 \mathrm{mg} / \mathrm{kg}$ dengan persentase peningkatan sebesar $2873,42 \%$ sedangkan yang paling menurun adalah lisin yaitu sebesar $-0,5278 \mathrm{mg} / \mathrm{kg}$ dengan persentase sebesar $85,17 \%$. Sementara itu, asam amino nonesensial yang mengalami peningkatan konsentrasi tertinggi adalah serin yaitu sebesar 0,0081 $\mathrm{mg} / \mathrm{kg}$ dengan persentase sebesar $900,00 \%$, sedangkan yang mengalami penurunan adalah asam aspartat yaitu sebesar $-0,0120 \mathrm{mg} / \mathrm{kg}$ dengan persentase sebesar $-35,40 \%$.

Konsentrasi asam amino histidin mengalami peningkatan dikarenakan tidak terbentuknya histamin. Histamin merupakan senyawa amina biogenik yang dihasilkan dari proses dekarboksilasi histidin bebas ( $\alpha$ - amino- $\beta$-imidazolasampropionat) (Lehane dan Olley, 1999). Proses pembentukan histamin pada ikan (Gambar 2) sangat dipengaruhi oleh aktivitas bakteri histidine decarboxylase positive yang akan membentuk enzim L-histidine decarboxylase (HDC). Enzim ini tidak dapat terbentuk karena pengaruh garam dan nira kelapa yang digunakan dalam proses pengolahan. Semakin lama penyimpanan nira maka semakin tinggi tingkat keasaman nira yang dapat menghambat adanya pertumbuhan bakteri histamin.<smiles>NCCc1c[nH]cn1</smiles>

Gambar 2. Dekarboksilasi Histidin menjadi Histamin

Hasil penelitian Pattirousamal (2018) tentang pemanfaatan nira kelapa untuk menurunkan kadar histamin pada ikan layang menunjukkan bahwa konsentrasi histamin $(\mathrm{mg} / 100 \mathrm{~g})$ terus menurun ketika semakin lama dilakukan perendaman dengan konsentrasi nira kelapa yang semakin tinggi. Lama perendaman pada pagi hari berlanjut ke siang hari dan siang, sore, menggunakan nira kelapa 5 ppm menunjukkan hasil penurunan konsentrasi histamin $(\mathrm{mg} / 100 \mathrm{~g})$ sebesar 65,5299 ; menjadi 24,5766; dan selanjutnya menjadi 20,4477. Pada kondisi perendaman ikan dengan nira kelapa 10 ppm diperoleh konsentrasi histamin menurun dari 43,8819; menjadi 22,5021; dan selanjutnya menjadi 11,2718) pada selang waktu yang sama. Pada konsentrasi nira kelapa 15 ppm diperoleh konsentrasi histamin juga menurun dari 29,4239; menjadi 17,0580; dan selanjutnya menjadi 10,4651 . Demikian halnya perendaman dengan nira kelapa 20 ppm diperoleh 22,6377; menjadi 14,8186; dan selanjutnya menjadi 7,0499 . Hal ini menunjukkan bahwa semakin lama proses perendaman ikan menggunakan nira kelapa dan semakin tinggi konsentrasinya maka histamin akan sulit terbentuk.

Selain mengalami peningkatan, 2 jenis asam amino mengalami penurunan konsentrasi setelah dihidrolisis asam. Menurunnya konsentrasi asam amino juga dapat terjadi karena adanya reaksi antara asam amino yang satu dengan yang lain, misalnya terbentuknya lisiolalanin dari lisin dan alanin. Hal ini menjelaskan, perubahan konsentrasi L-lisin sebelum pengolahan $(0,6917 \mathrm{mg} / \mathrm{kg})$ menjadi $(0,0919 \mathrm{mg} / \mathrm{kg})$ setelah pengolahan, dengan persentase penurunan sebesar $85,17 \%$. Persentase perubahan konsentrasi asam amino ikan Layang Deles

(Decapterus makrosoma) setelah pengolahan terlihat pada Gambar 3. 


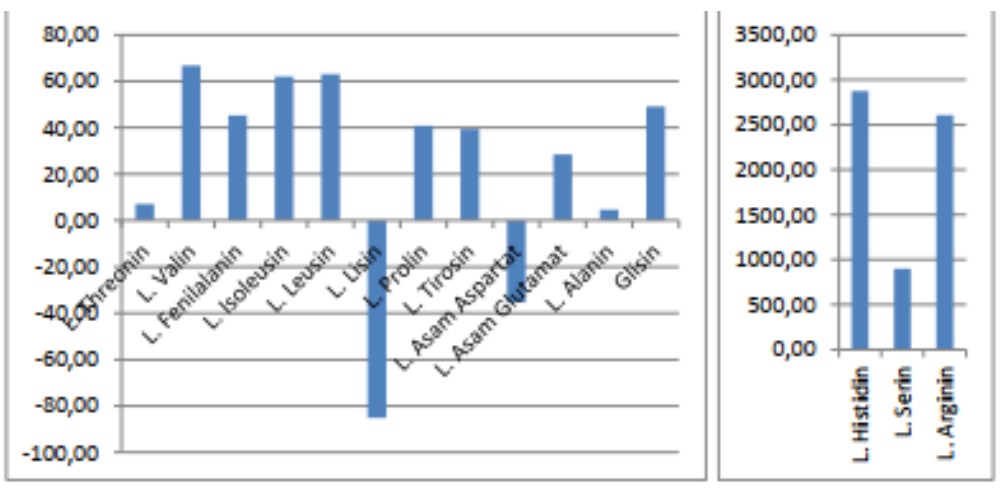

Gambar 3. Persentase perubahan konsentrasi asam amino (hidrolisis asam) sesudah pengolahan menjadi inmana

\section{Analisis komponen asam amino ikan Layang Deles (Decapterus makrosoma) segar dan ikan Inmana yang dihidrolisis secara basa}

Analisis 15 komponen asam amino ikan Layang Deles (Decapterus makrosoma) segar dan hasil olahan inmana yang dihidrolisis secara basa, dilakukan dengan menggunakan instrument Ultra Performance Liquid Chromatograpy (UPLC). Hasil analisis komponen asam amino pada ikan Layang Deles yang dihidrolisis secara basa dicantumkan pada Lampiran 2, sementara visualisasinya disajikan pada Gambar 4 berikut ini:

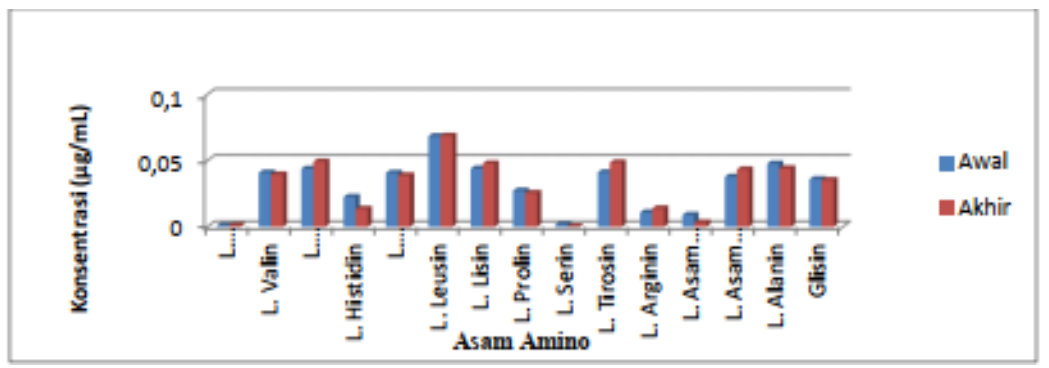

Gambar 4. Histogram konsentrasi asam amino hasil hidrolisis basa, ikan Layang Deles (Decapterus makrosoma) segar dan ikan Inmana

Histogram konsentrasi asam amino ikan Layang Deles (Decapterus makrosoma) yang dihidrolisis secara basasebelum dan sesudah pengolahan terhadap15 jenis asam amino menunjukkan adanya peningkatan maupun penurunan konsentrasi asam amino. Data Tabel 3 memperlihatkan bahwa konsentrasi tertinggi asam amino esensial ikan Layang Deles (Decapterus akrosoma) segar yang dihidrolisis secara basa adalah leusin yaitu sebesar $0,6837 \mathrm{mg} / \mathrm{kg}$, sedangkan yang terendah adalah threonin yaitu sebesar $0,0070 \mathrm{mg} / \mathrm{kg}$. Sementara itu, konsentrasi asam amino non esensial yang tertinggi adalah alanin yaitu sebesar $0,4768 \mathrm{mg} / \mathrm{kg}$ dan yang terendah adalah serin yaitu sebesar $0,0169 \mathrm{mg} / \mathrm{kg}$. Setelah pengolahan menjadi ikan asin inmana, asam amino esensial yang mengalami peningkatan tertinggi adalah threonin yaitu sebesar $0,0010 \mathrm{mg} / \mathrm{kg}$ dengan persentase peningkatan sebesar $14,29 \%$ dan yang paling mengalami penurunan konsentrasi adalah histidin yaitu sebesar $-0,0900 \mathrm{mg} / \mathrm{kg}$ dengan persentase $-40,02 \%$. Selain itu, asam amino non-esensial yang mengalami peningkatan konsentrasi tertinggi adalah arginin yaitu sebesar $0,0310 \mathrm{mg} / \mathrm{kg}$ dengan persentase $28,73 \%$, dan yang paling mengalami penurunan konsentrasi adalah serin yaitu sebesar $-0,0149 \mathrm{mg} / \mathrm{kg}$ dengan persentase $-88,17 \%$. 
Tabel 3. Hasil analisis konsentrasi asam amino ikan layang (Decapterus makrosoma) segar dan ikan asin inmana yang dihidrolisis secara basa

\begin{tabular}{|c|c|c|c|c|c|c|}
\hline \multirow{2}{*}{ No } & \multirow{2}{*}{ Asam Amino } & \multicolumn{2}{|c|}{ Konsentrasi (mg/kg) } & \multicolumn{2}{|c|}{ Perubahan konsetrasi } & \multirow[b]{2}{*}{ Ket } \\
\hline & & Awal & Akhir & $(\mathrm{mg} / \mathrm{Kg})$ & $\%$ & \\
\hline $\mathbf{I}$ & \multicolumn{5}{|c|}{ Asam Amino Esensial } & \\
\hline 1. & L. Threonin & 0,0070 & 0,0080 & 0,0010 & 14,29 & $\uparrow$ \\
\hline 2. & L. Valin & 0,4088 & 0,3948 & 0,0140 & 3,42 & $\downarrow$ \\
\hline 3. & L. Fenilalanin & 0,4378 & 0,4918 & 0,0540 & 12,33 & $\downarrow$ \\
\hline 4. & L. Histidin & 0,2249 & 0,1349 & 0,0900 & 40,02 & $\downarrow$ \\
\hline 5. & L. Isoleusin & 0,4058 & 0,3878 & 0,0180 & 4,44 & $\downarrow$ \\
\hline 6. & L. Leusin & 0,6837 & 0,6877 & 0,0040 & 0,59 & $\lambda$ \\
\hline 7. & L. Lisin & 0,4388 & 0,4778 & 0,0390 & 8,89 & $\uparrow$ \\
\hline II & \multicolumn{5}{|c|}{ Asam Amino non-Esensial } & \\
\hline$\overline{1 .}$ & L. Prolin & 0,2728 & 0,2548 & 0,0180 & 6,59 & $\downarrow$ \\
\hline 2. & L. Serin & 0,0169 & 0,0020 & 0,0149 & 88,17 & $\downarrow$ \\
\hline 3. & L. Tirosin & 0,4108 & 0,4848 & 0,0740 & 18,01 & $\uparrow$ \\
\hline 4. & L. Arginin & 0,1079 & 0,1389 & 0,0310 & 28,73 & $\uparrow$ \\
\hline 5. & L. Asam Aspartat & 0,0889 & 0,0329 & 0,0560 & 62,99 & $\downarrow$ \\
\hline 6. & L. Asam Glutamat & 0,3768 & 0,4328 & 0,0560 & 14,86 & 争 \\
\hline 7. & L. Alanin & 0,4768 & 0,4408 & 0,0360 & 7,55 & $\downarrow$ \\
\hline 8. & Glisin & 0,3588 & 0,3528 & 0,0060 & 1,67 & ¿ \\
\hline
\end{tabular}

Berdasarkan data di atas dapat disimpulkan bahwa dari total 15 jenis asam amino ( 7 asam amino esensial dan 8 asam amino non-esensial), 4 asam amino esensial mengalami peningkatan konsentrasi dan 3 lainnya mengalami penurunan konsentrasi. Sementara itu, 5 jenis asam amino non esensial mengalami penurunan konsentrasi dan 3 lainnya mengalami peningkatan. Persentase perubahan konsentrasi asam amino ikan Layang Deles (Decapterus makrosoma) setelah pengolahan terlihat pada Gambar 5.

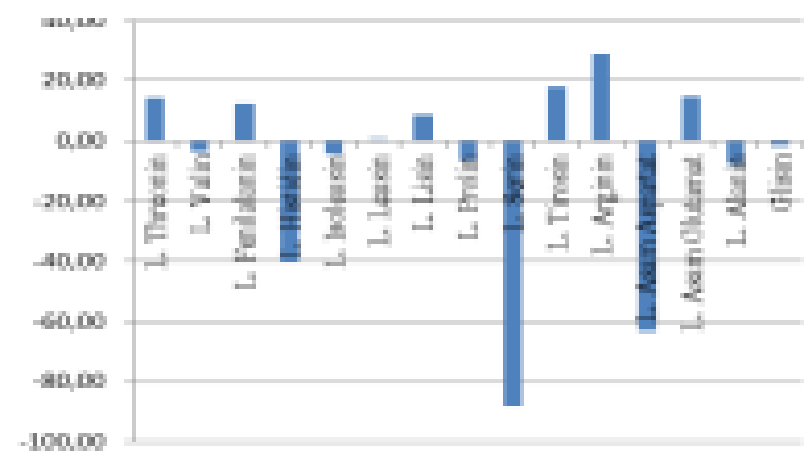

Gambar 5. Persentase perubahan konsentrasi asam amino (hidrolisis basa) sesudah pengolahan menjadi Inmana

\section{KESIMPULAN}

Berdasarkan hasil penelitian yang telah dilakukan maka dapat disimpulkan bahwa pengolahan ikan inmana dengan lama waktu penyimpanan 2 bulan makrosoma). Perubahan konsentrasi 15 jenis asam amino yang diukur berkisar antara $85,17 \%$ sampai dengan $2873,42 \%$ pada hidrolisis asam dan antara $88,18 \%$ sampai dengan $28,73 \%$ pada hidrolisis basa. Perubahan terbesar terjadi 
pada konsentrasi asam amino histidin, arginin dan serin yakni sebesar $2873,42 \%, 2606,74 \%$, $900,00 \%$ pada hidrolisis asam dan pada asam amino serin, asam aspartat dan histidin yakni sebesar $88,17 \%, 62,99 \%, 40,02 \%$ pada hidrolisis basa.

\section{DAFTAR PUSTAKA}

Buckle, K. A., Edwards, R. A., dan Wootton, M. 1987. (buku Asli diterbitkan tahun 1985). Ilmu Pangan (Terjemahan Hari Purnomo Adiono). Jakarta: Universitas Indonesia Press. Hafiludin. 2011. Karakteristik Proksiimat dan Kandungan Senyawa Kimia Daging Putih Dan Daging Merah Ikan Tongkol (Euthynnnus Affinis). Jurnal Kelautan Vol. 4. No. 1. ISSN 1907-9931. Hal 1-11. Haris, S., 2013. Pengaruh Penggaraman Terhadap Protein Ikan Layang (Decapterus Rusell). Jurnal Ilmiah Mahasiswa Universitas Surabaya. Vol.2 No.1. Hal 1-11.

Lehane L., dan Olley J., 1999, Histamine(Scombroid) Fish Poisoning, a Review ina Risk-Assessment Framework, National Office of Animal and Plant Healt, Canberra, iv +80 pp.

Mazrouh M. M., 2015. Effects of freezing storage on the biochemical composition in muscles of Saurida undosquamis (Richardson, 1848) comparing with imported frozen. International Journal of Fisheries and Aquatic Studies; IJFAS 3(2): 295-299. ISSN: 2347-5129. Hal 295299. Murniyanti, A.S., dan Sunarman, 2000. Pendinginan, Pembekuan dan Pengawetan. Kanisius: Yogyakarta

Paparang, W. R., 2013. Studi Pengaruh Variasi Konsentrasi Garam Terhadap Citarasa Peda Ikan Layang (Decapterus Russelli). Jurnal Media Teknologi Hasil Perikanan. Vol.1 No 1. Hal 17-20.

Patirousamal, I., 2018. Pemanfaatan Nira Kelapa Untuk Menurunkan Kadar Histamin pada Ikan Layang (Decapterus Sp). Skripsi Jurusan Kimia. Fakultas Matematika dan IImu Pengetahuan Alam. Universitas Pattimura.

Purbasari D., 2008. Produkse dan Karakterisasi HidrolisatProtein dari Kerang Mas Ngur (Atactodea Striata). Skripsi. Program Studi Teknologi Hasil Perikanan. Fakultas Perikanan Institut Teknologi Bogor.

Reo A., 2013. Mutu Ikan Kakap Merah Yang Diolah Dengan Perbedaan Konsentrasi Larutan Garam dan Lama Pengeringan. Jurnal Perikananan dan Kelautan Tropis. Vol 9, No 1, Hal. 3544.

Riansyah, A., Supriadi, A., dan Nopianti, R., 2013. Pengaruh Perbedaan Suhu dan Waktu Pengeringan Terhadap Karakteristik Ikan Asin Sepat Siam (Trichogaster Pectoralis) dengan Menggunakan Oven. Fishtech. Vol.2 No.1. Hal: 53-68

Rumahlaiselan, D., 2016. Analisis Komponen Asam Lemak Pada Ikan Ina Sua (Ikan Asin) Hasil lahan Ikan Kakap Merah (Lutjanus sp). Skripsi Program Studi Pendidikan Kimia. Jurusan Pendidikan MIPA, Fakultas Keguruan dan IImu Pendidikan, Universitas Pattimura Ambon.

Salosa, Y.Y., 2013. Uji Kadar Formalin, Kadar Garam dan Total Bakteri Ikan Asin Tenggiri Asal Kabupaten Sarmi Provinsi Papua. Jurnal Ilmu Perairan, Pesisir dan Perikanan. Vol. 2.No. ISSN 2089-7790. Hal 10-15.

Susilowati, E., 2010. Kajian Aktivitas Antioksidan, Serat Pangan, dan Kadar Amilosa pada Nasi yang Disubstitusi Dengan Ubi Jalar (Ipomea batatas L) Sebagai Bahan Makanan Pokok. Skripsi. Program Studi Teknologi Hasil Pertanian. Fakultas Pertanian. Universitas Sebelas Maret; Surakarta.

Winarno, F. G., 2004. Kimia Pangan dan Gizi. Gramedia: Jakarta.

Yuarni, D., Kadirman., Dan Jamaluddin. 2015. Laju Perubahan Kadar Air, Kadar Protein Dan Uji Organoleptik Ikan Lele Asin Menggunakan Alat Pengering Kabinet (Cabinet Dryer) Dengan Suhu Terkontrol. Jurnal Teknologi Pertanian. Vol: 1. Hal: $12-21$. 